\title{
Phytoplankton-bacterioplankton coupling in a subtropical South Pacific coral reef lagoon
}

\author{
E. J. Rochelle-Newall ${ }^{1,2, *}$, J.-P. Torréton ${ }^{1,2}$, X. Mari $^{1}$, O. Pringault ${ }^{1}$ \\ ${ }^{1}$ UR 103, CAMELIA, Centre IRD Nouméa, BP A5, Nouméa, New Caledonia \\ ${ }^{2}$ Present address: ECOLAG, UMR 5119, Université Montpellier II, Case 093, 34095 Montpellier, France
}

\begin{abstract}
Tropical coastal ecosystems are often ignored in carbon cycling budgets even though it is now recognised that these ecosystems can be important in terms of coastal carbon cycling. We present results from a series of incubations conducted during a $10 \mathrm{~d}$ cruise in the southwest lagoon of New Caledonia, southwestern Pacific, aimed at examining phytoplankton-bacterioplankton coupling. We measured primary production, including dissolved (DPP) and particulate (PPP) primary production, and bacterial production (BP, ${ }^{3} \mathrm{H}$-thymidine method) along a gradient. Regardless of inorganic nutrient concentration, we failed to see a tight coupling over the short term (4 $\mathrm{h}$ incubation) between net DPP and BP. A negative relationship between BP and the photosynthetic response to light was observed, leading to a decreased $\triangle \mathrm{BP}$ :DPP ratio with increasing photon flux density. However, when all the data were compiled, BP was correlated with DPP and total primary production. Assuming bacterial growth efficiencies from 1 to $10 \%$, bacterial carbon demand (BCD) was higher than the supply of DPP in the most oligotrophic sites (up to $400 \%$ of DPP). This implies a weaker linkage between bacteria and phytoplankton than previously observed in other oligotrophic sites and requires external subsidies of dissolved organic carbon. In the coastal sites, characterised by higher inorganic and organic matter concentrations, DPP was estimated as being sufficient to support BCD, and bacteria and phytoplankton are considered to be strongly linked. These results were in contrast to previously published results for temperate and polar coastal regions and highlight the differences of these often understudied tropical systems.
\end{abstract}

KEY WORDS: Dissolved primary production - Bacterial production - DOC $\cdot$ Tropical ecosystems · Carbon cycling

\section{INTRODUCTION}

Dissolved organic matter (DOM) is produced during photosynthesis (Marañón et al. 2004) and forms the principal source of new DOM in the open ocean. The recycling of DOM by heterotrophic bacteria is one of the major transformation pathways of organic matter (Carlson 2002, del Giorgio \& Davis 2003). It is therefore intuitive that there might be a tight relationship between the production of organic matter by autotrophic processes and the removal of organic matter by heterotrophic processes, particularly in sites isolated from external inputs. In a review, Cole et al. (1988) showed that this linkage generally holds and this has been further confirmed by Morán et al. (2002b).

The relationship between bacterial production (BP) or bacterial carbon demand (BCD) and primary production varies as a function of the ecosystem characteristics. There is a general trend of loose linkage in coastal or eutrophic sites and tight linkage in open ocean sites, at least for the temperate and polar environments examined to date (Cole et al. 1988, Morán et al. 2002a). In open ocean sites, far from allochthonous DOM sources, BCD and dissolved primary production (DPP) are often tightly linked, indicating that the supply of carbon from DPP supports BCD, although this 
paradigm has been questioned by Teira et al. (2003) in open-ocean gyre systems. In contrast, in coastal sites, where allochthonous sources of DOM can be important, BCD is met by not only DPP but also by DOM from alternative sources, such as runoff, riverine inputs and benthic release.

DOM is a complex mixture of organic carbon moieties and the rates of DOM uptake and remineralisation by bacterial heterotrophs vary immensely. It has been suggested that DOM can be divided into 3 main classes: labile, semi-labile and refractory, as a function of the degradation rates by heterotrophic bacteria (Kirchman et al. 1993, Carlson et al. 1994). Amon \& Benner (1996) further extended this idea and proposed that high-molecular-weight DOM was generally more bioavailable, or labile, than low-molecular-weight DOM. This was questioned by other authors working on terrestrial and riverine DOM (Stepanauskas et al. 1999, Rochelle-Newall et al. 2004); however, it is generally accepted that DOM released during photosynthesis is highly bioavailable to bacterial heterotrophs (Norrman et al. 1995).

Tropical coral lagoonal systems present an interesting environment for the study of carbon cycling. These coastal environments are often characterised by low nutrient and chlorophyll concentrations, elevated temperatures and high light penetration. Organic matter concentrations are often very low and oligotrophic conditions generally persist. Several studies have examined bacterial processes (Torréton \& Dufour 1996) and autotrophic production (Jacquet et al. 2006) or $\mathrm{CO}_{2}$ fluxes (Borges et al. 2005) in coastal tropical systems, but few have examined the degree of coupling between bacterial and primary production; those that have generally focused on eutrophic systems and lakes (Bouvy et al. 1998) or on oligotrophic gyre systems away from coastal influences (Teira et al. 2003).

The southwest lagoon of New Caledonia is an oligotrophic system that is regularly flushed by seawater that enters the lagoon at the southern end (Douillet et al. 2001). In contrast to the oligotrophic lagoonal waters, in the inshore areas and particularly in the coastal bays, seawater is enriched with nutrients originating from urban and industrial sources (Torréton et al. 2007). This environment is characterised by very low riverine inputs and, consequently, salinity does not vary greatly. This results in a gradient of nutrients and chlorophyll which is ideal for testing the degree of cou- pling between BP and primary production along a gradient without the confounding effects of salinity changes (Jacquet et al. 2006).

We present the results from an investigation into the degree of coupling between BP and primary production. The objectives of this work were to determine whether the previously reported links between BP and primary production exist in a subtropical coral reef lagoonal environment, and whether DPP provides sufficient carbon for bacterial respiratory and growth demands.

\section{MATERIALS AND METHODS}

Samples were collected from a depth of $3 \mathrm{~m}$ during a 2 wk cruise in the southwest lagoon of New Caledonia from 18 to 27 October 2004. Ten stations covering a range of anticipated chlorophyll concentrations were sampled (Fig. 1). Particulate primary production (PPP), $\mathrm{DPP}, \mathrm{BP}$, inorganic and organic nutrients, total organic carbon (TOC), and transparent exopolymer particles (TEP) were also measured. At each sampling station, a CTD profiler (SeaBird SBE19) was also deployed to measure temperature, salinity, photosynthetically active radiation (PAR) and in vivo fluorescence profiles.

PPP and DPP were measured using $\mathrm{NaH}^{14} \mathrm{CO}_{3}$ (Marañón et al. 2005). Duplicate $63 \mathrm{ml}$ water samples were inoculated with either 0.22 (Stns D65 and N12), 0.44 (Stns D43 and D47), 0.66 (Stns M36, N43 and M33) or $1.2 \mathrm{MBq}$ (Stns A17, A25 and A28) of $\mathrm{NaH}^{14} \mathrm{CO}_{3}$ (Perkin-Elmer), depending on the anticipated trophic status of the sample, and incubated in an on-board flowing seawater incubator. Neutral density screening

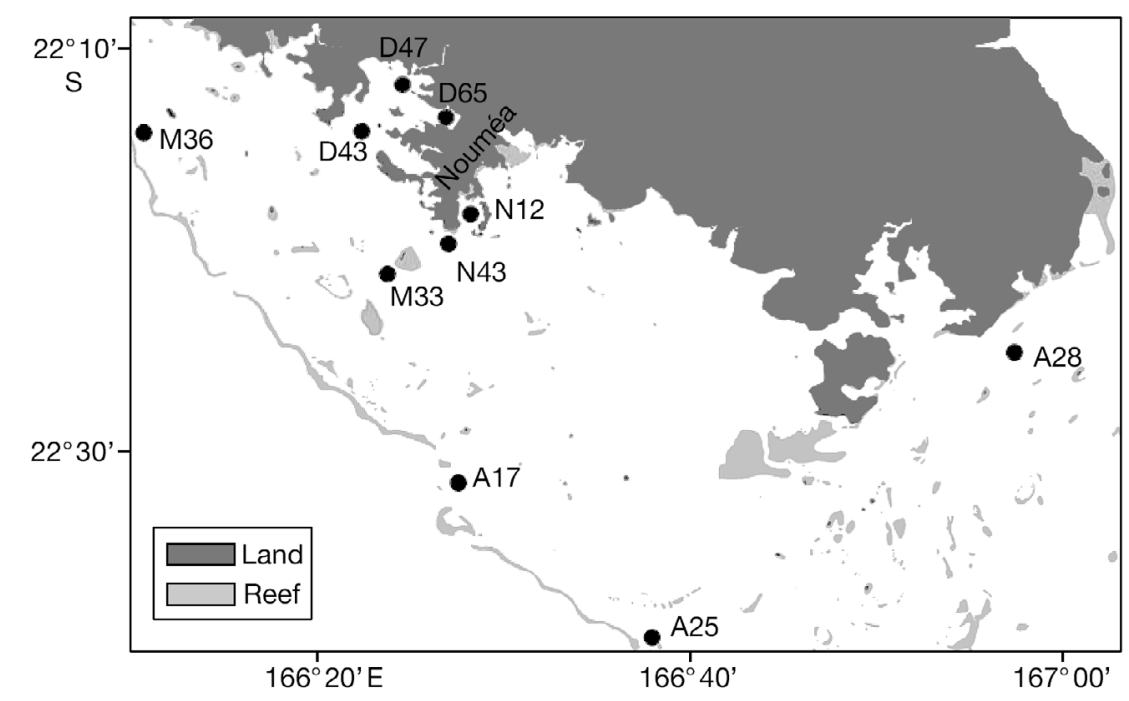

Fig. 1. Study area in the southwest lagoon of New Caledonia, including the stations used for primary production measurements and the city of Nouméa 
was used to simulate a light gradient $(0,6.25,12.5,25$, 50 and $100 \%$ incident irradiation). The photon flux density received by the incubations was measured using a LiCOR detector attached to the side of the incubator. After $4 \mathrm{~h}$ incubation, generally somewhere between 09:00 and 14:00 h, samples were carefully filtered at low vacuum pressure onto $0.4 \mu \mathrm{m}$ polycarbonate filters (Whatman Cyclopore). After acidification and drying of the filters $\left(24 \mathrm{~h}\right.$ at $\left.45^{\circ} \mathrm{C}\right), 5 \mathrm{ml}$ of scintillation cocktail (Ultima Gold, Packard Instruments) was added. The amount of ${ }^{14} \mathrm{C}$ incorporated into the particulate phase (PPP) was calculated using an inorganic carbon concentration of $25700 \mu \mathrm{g} \mathrm{C} \mathrm{l}^{-1}$ (Marañón et al. 2004). For the DPP measurement, duplicate $5 \mathrm{ml} \mathrm{sam-}$ ples of filtrate were collected, acidified with $100 \mu \mathrm{l}$ of $5 \mathrm{~mol} \mathrm{l}^{-1} \mathrm{HCl}$ and left for $12 \mathrm{~h}$ on a horizontal agitator table. A test prior to the incubations showed that the volume of acid and agitation time were sufficient to remove all the inorganic ${ }^{14} \mathrm{C}$ remaining in the filtrate. After acidification, $15 \mathrm{ml}$ of scintillation cocktail (Ultima Gold XR, Packard Instruments) was added and the samples counted. All measurements of DPP were between 2 and 10 times that of the dark-bottle incubations (abiotic uptake blank) that were conducted in parallel. Total primary production (TPP) is calculated by summing DPP and PPP, and the percentage extracellular release (PER) is calculated by dividing DPP by TPP.

$\mathrm{BP}$ was measured before incubation $\left(\mathrm{BP}_{\mathrm{ini}}\right)$ and at the end of the primary production experiments using the ${ }^{3} \mathrm{H}$-thymidine method (Torréton \& Dufour 1996, Torréton et al. 2007). Briefly, duplicate $5 \mathrm{ml}$ (coastal bay stations) or $10 \mathrm{ml}$ water samples were incubated in the dark with ${ }^{3} \mathrm{H}$-[methyl]thymidine (final concentration $15 \mathrm{nM}, 1.8 \mathrm{TBq} \mathrm{mmol}^{-1}$, Amersham) for $1 \mathrm{~h}$ at in situ temperature $\left( \pm 1^{\circ} \mathrm{C}\right)$. Previous experiments have shown that saturation is always obtained at this concentration. After terminating the incubation with buffered formalin ( $2 \%$ final concentration), the labelled material was collected by filtration under low pressure $(<100 \mathrm{~mm}$ $\mathrm{Hg}$ ) through a $0.2 \mu \mathrm{m}$ polycarbonate membrane and allowed to precipitate for $15 \mathrm{~min}$ at $4^{\circ} \mathrm{C}$ with ice-cold trichloroacetic acid (TCA; $5 \% \mathrm{w} / \mathrm{v})$. Membranes were rinsed 3 times with $5 \mathrm{ml}$ cold $5 \%$ TCA. The amount of radioactivity incorporated into the cells was measured with a Packard TriCarb scintillation counter after addition of $4 \mathrm{ml}$ scintillation cocktail (Ultima Gold, Packard Instruments). Rates of ${ }^{3} \mathrm{H}$-thymidine incorporation were converted to cell production using a conversion factor of $2.91 \times 10^{18}$ cells mol $^{-1}$ thymidine (S. Jacquet unpubl. data) and $12.4 \mathrm{fg} \mathrm{C} \mathrm{cell}^{-1}$ (Fukuda et al. 1998).

In order to measure BP within the light incubations, a parallel incubation was run using an identical protocol to the ${ }^{14} \mathrm{C}$ measurement, the only difference being that no ${ }^{14} \mathrm{C}$ was added. At the end of the $4 \mathrm{~h}$ incubation, as with $\mathrm{BP}_{\text {ini, }}$ duplicate $5 \mathrm{ml}$ subsamples were collected for measurement of BP. This incubation was conducted in the dark using the same method for the $\mathrm{BP}_{\text {ini }}$ measurements. The $1 \mathrm{~h}$ dark incubation was used to avoid any direct influence of light on the measurement of BP and to evaluate the bioavailability of any recently produced DPP, and hence any degree of linkage between bacterial and phytoplanktonic activities. We thus had 2 dark measurements of $\mathrm{BP}$ : one initial $\left(\mathrm{BP}_{\text {ini }}\right)$ and one after $4 \mathrm{~h}$ incubation in the presence of light $\left(\mathrm{BP}_{\text {fini }}\right.$ $0,6.25,12.5,25,50$ and $100 \%$ incident irradiation).

An index of the percentage change in BP was calculated $(\triangle \mathrm{BP}$ in $\%)$ in order to estimate the relative change in $\mathrm{BP}$ after $4 \mathrm{~h}$ incubation at each respective light level and is calculated as:

$$
\Delta \mathrm{BP}=\frac{\mathrm{BP}_{\text {fin }}-\mathrm{BP}_{\text {ini }}}{\mathrm{BP}_{\text {ini }}} \times 100
$$

Nitrate and nitrite concentrations were determined according to Raimbault et al. (1990) on a Bran+Luebbe Autoanalyzer III with an average detection limit and coefficient of variation (CV) of $20 \mathrm{nmol} \mathrm{l}^{-1}$ and $3 \%$ and $2 \mathrm{nmol} \mathrm{l}^{-1}$ and $8 \%$ for eutrophic and oligotrophic waters, respectively. Ammonium was fluorometrically determined on a Turner TD-700 immediately after collection using the $o$-phthaldialdehyde method (Holmes et al. 1999). Dissolved inorganic nitrogen (DIN) is the sum of $\mathrm{NO}_{3}{ }^{-}+\mathrm{NO}_{2}^{-}$and $\mathrm{NH}_{4}{ }^{+}$. Phosphate concentrations were determined on a Bran+Luebbe Autoanalyzer III with a detection limit of $10 \mathrm{nmol} \mathrm{l}^{-1}$ and an average CV of 6 to $11 \%$ between replicates (Torréton et al. 2007).

Chl a was analysed fluorometrically on methanol extracts (Holm-Hansen et al. 1965) following filtration onto Whatman GF/F filters of replicate $300 \mathrm{ml}$ samples.

Particulate organic carbon (POC) was determined on GF/F filters using a Perkin Elmer $2400 \mathrm{CHN}$ elemental analyser. TOC analyses were performed on $10 \mathrm{ml}$ subsamples collected in precombusted $\left(450^{\circ} \mathrm{C}\right.$, overnight) $10 \mathrm{ml}$ glass ampoules, preserved with $12 \mu \mathrm{l} 85 \%$ phosphoric acid $\left(\mathrm{H}_{3} \mathrm{PO}_{4}\right)$ and flame-sealed. Samples were stored in the dark until analysis. TOC concentration was measured on a Shimadzu TOC VCPH analyser, using potassium phthalate calibration standards over

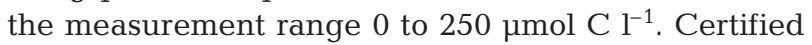
reference materials (Hansell Laboratory, University of Miami) were also used to assess the performance of the instrument on and between measurement days. The

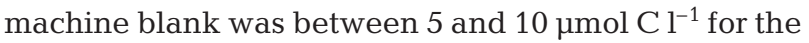
measurement days. Dissolved organic carbon (DOC) was calculated by subtracting the POC measurements from the TOC concentrations.

TEP concentrations were measured using the semiquantitative colorimetric method (Passow \& Alldredge 1995). This method allows the determination of TEP 
concentration $\left(\mathrm{TEP}_{\text {spectroi }}\right.$ xanthan equivalents $\mathrm{l}^{-1}$ ) by measuring the total amount of Alcian blue adsorbed to all particles, including TEP, that contain carboxylated and sulphated polysaccharides. Estimates of TEP carbon concentration (TEP-C) were calculated from colorimetric determinations (Engel \& Passow 2001) as follows: TEP-C $\mathrm{C}_{\text {spectro }}=0.75 \mathrm{TEP}_{\text {spectro }} / V$, where $V$ is the volume filtered $(\mathrm{ml})$.

\section{RESULTS}

The physico-chemical and biological variables for each sample site are presented in Table 1. In general, all sites had relatively low chl $a$ and nutrient concentrations. The only exceptions were the 2 stations (D65 and N12) located within the coastal bays surrounding the city of Nouméa (Fig. 1). Similarly, TOC concentrations were low (ca. 60 to $70 \mu \mathrm{M} \mathrm{C}$ ). Again, the only exceptions were Stns D65 and N12, where concentrations of almost $100 \mu \mathrm{M} \mathrm{C}$ were found. These variations in concentration were also reflected in the TEP-C concentrations, with the highest values observed at the bay stations (2.5 to $6.2 \mu \mathrm{M} \mathrm{C}$ ) and the lowest ( 0.1 to $1 \mu \mathrm{M} \mathrm{C}$ ) in the more oligotrophic sites.

Primary production and $\mathrm{BP}_{\text {ini }}$ followed similar trends, with higher rates measured at the inshore stations than in the offshore stations (Table 2), as has been previously noted in Mari et al. (2007) and Torréton et al. (2007). As would be expected, PPP and DPP increased with light level and there was little evidence of photoinhibition of PPP (Fig. 2). The only stations where photoinhibition at the $100 \%$ light level was observed were the 3 most oceanic sites (Stns A17, A25 and A28), where PPP was reduced by $20 \%$ relative to the $50 \%$ light level (Fig. 2A, Table 2). However, when TPP was considered, there was little evidence of photoinhibition, reflecting an increased DPP at the highest light level at these 3 stations. PER varied between 5 and $74 \%$ and showed little

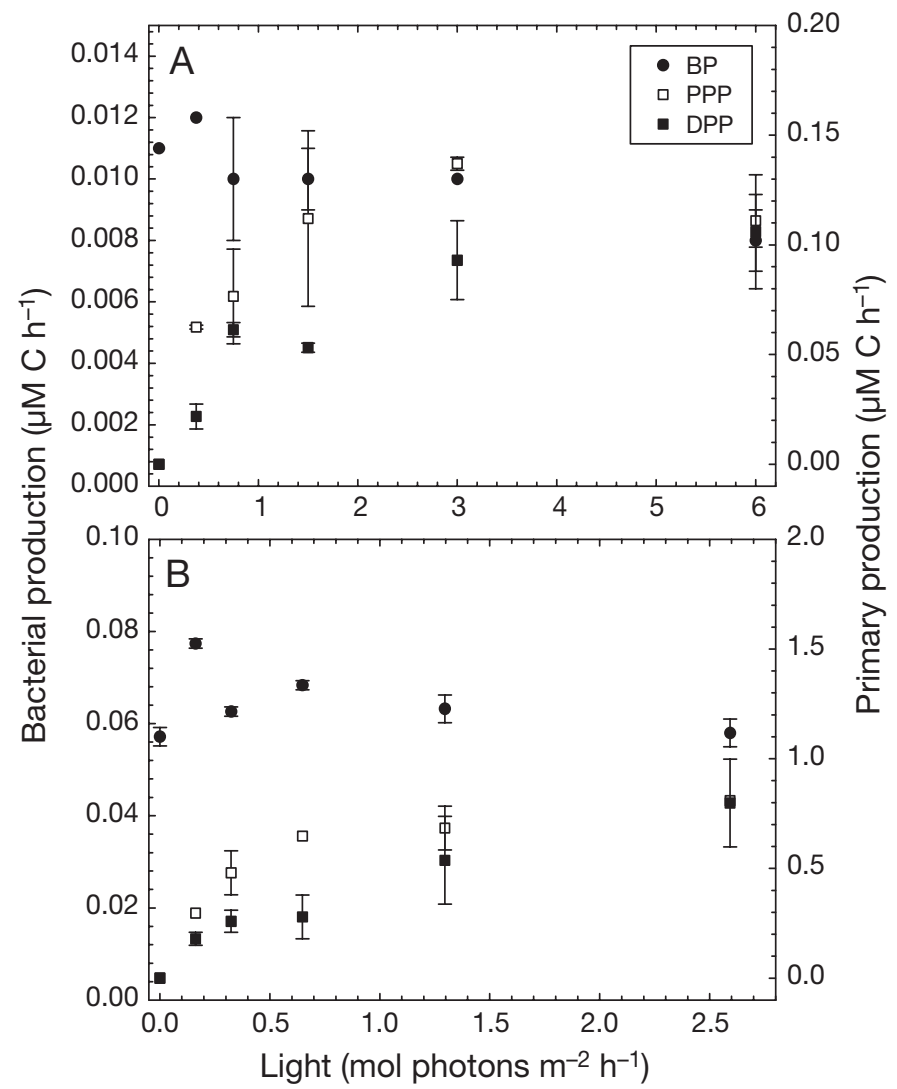

Fig. 2. Dissolved (DPP) and particulate (PPP) primary production and bacterial production (BP) in 2 contrasting stations. (A) Stn A25, an oligotrophic station in the southern end of the lagoon. (B) Stn N12 from one of the coastal bays. Note differences in scales between panels

pattern with increasing light level and was on average $35 \pm 15 \%$. The only exceptions occurred at Stns A17, A25 and A28, where higher PER levels (up to $74 \%$ ) were observed at the $100 \%$ light level.

BP generally increased in all the incubations relative to $\mathrm{BP}_{\text {ini }}$ (Table 2). However, degree of stimulation was

Table 1. Physico-chemical and biological variables for each sample site. DIN: dissolved inorganic nitrogen; TOC: total organic carbon; DOC: dissolved organic carbon; TEP-C: transparent exopolymer particles, carbon concentration

\begin{tabular}{|c|c|c|c|c|c|c|c|c|c|c|}
\hline $\begin{array}{l}\text { Date } \\
\text { (Oct 2004) }\end{array}$ & Stn & $\begin{array}{c}\text { Temp. } \\
\left({ }^{\circ} \mathrm{C}\right)\end{array}$ & Salinity & $\begin{array}{l}\text { Depth } \\
\text { (m) }\end{array}$ & $\begin{array}{c}\operatorname{chl} a \\
\left(\mu \mathrm{g}^{-1}\right)\end{array}$ & $\begin{array}{l}\mathrm{PO}_{4} \\
(\mu \mathrm{M})\end{array}$ & $\begin{array}{l}\text { DIN } \\
(\mu \mathrm{M})\end{array}$ & $\begin{array}{c}\text { TOC } \\
(\mu \mathrm{M} \mathrm{C})\end{array}$ & $\begin{array}{c}\text { DOC } \\
(\mu \mathrm{M} \mathrm{C})\end{array}$ & $\begin{array}{l}\text { TEP-C } \\
(\mu \mathrm{M})\end{array}$ \\
\hline 18 & D65 & 24.1 & 36.3 & 7 & 2.14 & 0.663 & 0.363 & 121.1 & 99.3 & 6.2 \\
\hline 19 & D43 & 23.6 & 36.0 & 15 & 0.34 & 0.011 & 0.019 & 67.8 & 61.1 & 2.5 \\
\hline 19 & D47 & 23.5 & 36.0 & 10 & 0.44 & 0.027 & 0.087 & 71.0 & 65.2 & 1.6 \\
\hline 20 & M36 & 22.8 & 35.9 & 12 & 0.25 & 0.056 & 0.073 & 67.8 & 61.7 & 0.1 \\
\hline 21 & N12 & 23.0 & 36.0 & 12 & 1.17 & 0.070 & 0.242 & 104.4 & 96.1 & 2.8 \\
\hline 21 & N43 & 22.8 & 35.9 & 21 & 0.30 & 0.036 & 0.144 & 65.1 & 60.7 & 1.0 \\
\hline 22 & M33 & 22.9 & 35.8 & 23 & 0.36 & 0.032 & 0.067 & 61.7 & 56.5 & 0.6 \\
\hline 25 & A17 & 22.8 & 35.7 & 64 & 0.21 & 0.058 & 0.032 & 63.5 & 59.9 & 1.5 \\
\hline 26 & A25 & 22.5 & 35.7 & 40 & 0.31 & 0.056 & 0.142 & 58.3 & 54.8 & 1.3 \\
\hline 26 & A28 & 22.5 & 35.5 & 50 & 0.48 & 0.075 & 0.223 & 61.6 & 55.9 & 1.4 \\
\hline
\end{tabular}




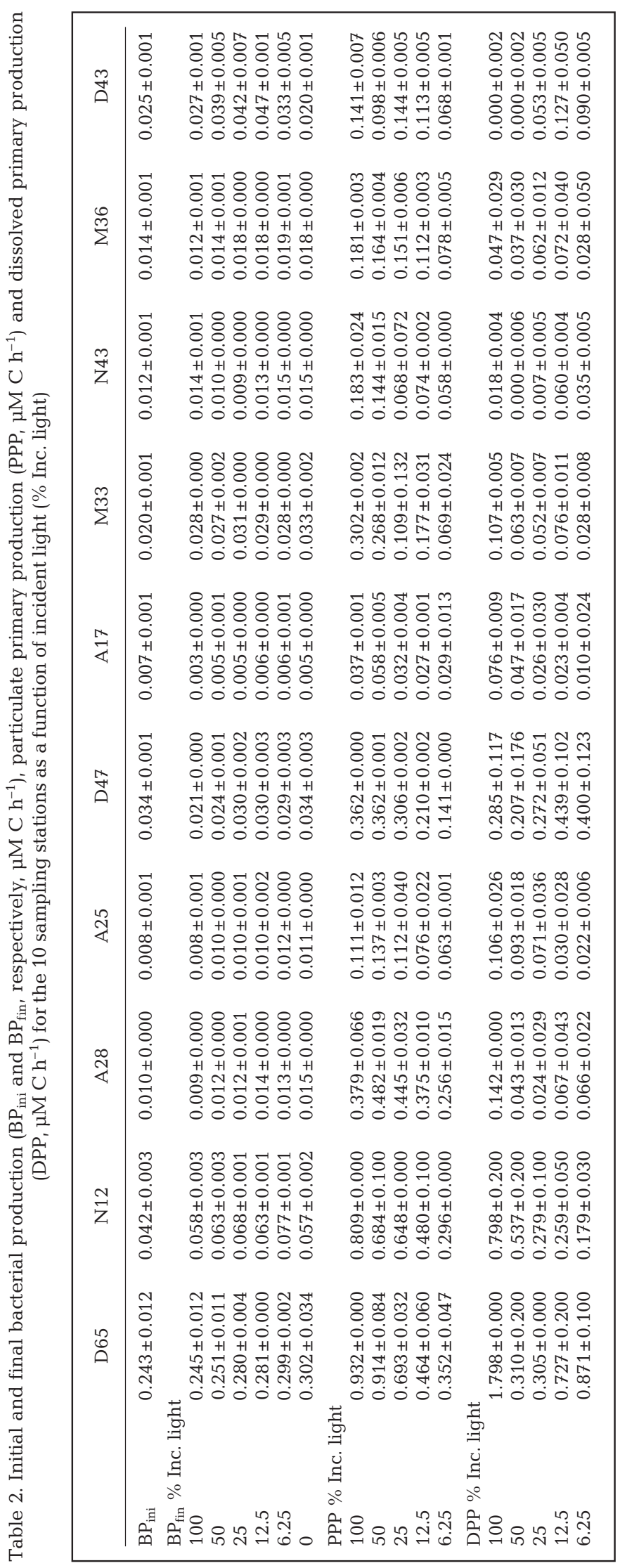

not constant and actually decreased with increasing incubation light level and hence TPP level. This resulted in BP in the $100 \%$ light level incubations that was lower

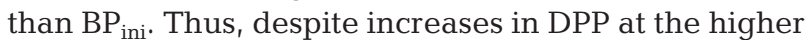
light levels, BP generally did not increase with increasing light. In the majority of the incubations (6 out of 10 ), regardless of the incubation light level and the origin of the water sample, BP at the 2 lowest light levels ( 0 and $6 \%$ ) was higher than that of the incubations at the higher light levels (50 and $100 \%$ ). The only exceptions were found at Stns A17, M33, D43 and N12, where an increase in BP relative to incubation light level was observed at the low to intermediate light levels followed by a decrease at the higher light levels (Table 2). On average, comparing all the data from each light level, the relative percent increase in $\mathrm{BP}$ over the course of the incubation $(\triangle \mathrm{BP})$ was lowest at the higher light levels (Fig. 3A). Moreover, when all of the data were pooled and compared, there was a significant decrease $\left(\mathrm{r}^{2}=0.84, \mathrm{p}<0.05\right)$ in the ratio of $\triangle B P$ :DPP as a function of percent incident light (Fig. 3B).

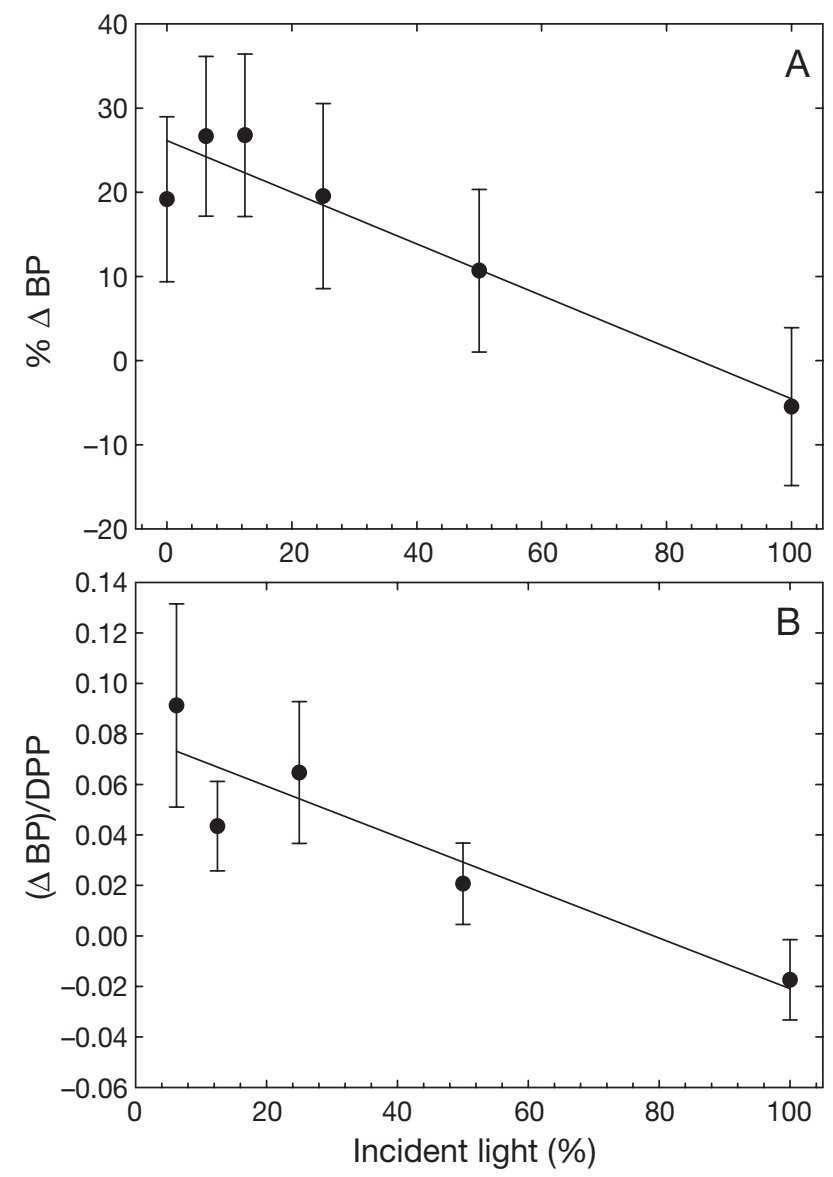

Fig. 3. Response of bacterial production (BP) as a function of percentage incident light. (A) Percentage change in BP $\left(\mathrm{r}^{2}=\right.$ $0.89, \mathrm{p}<0.01$ ). (B) Relative change in BP:dissolved primary production (DPP) ratio $\left(\mathrm{r}^{2}=0.84, \mathrm{p}<0.05\right)$ 
Morán et al. (2002b) suggested that BCD was a better parameter of phytoplankton-bacterioplankton coupling than BP alone. We do not have contemporaneous measurements of bacterial respiration and so, following the example of Morán et al. (2002a), we have used the relationship between BP and bacterial growth efficiency (BGE) of del Giorgio \& Cole (1998) to calculate BCD. The BGE determined from the relationship of del Giorgio \& Cole (1998) were similar to those previously determined in the lagoon by Briand et al. (2004) and varied between 1 and $10 \%$ for the stations examined in the present study. Although $\mathrm{BP}_{\text {fin }}$ alone is correlated with both TPP and DPP, the points all fall below the 1:1 line, indicating that rates of TPP are higher than $\mathrm{BP}_{\text {fin }}$ rates (Fig. 4A,B). When estimated bacterial respiration is combined with $\mathrm{BP}_{\text {fin }}$ to give an estimation of $\mathrm{BCD}$, a different pattern emerges resulting in a reduction in the slope of the relationship between the supply and demand of organic carbon (Fig. 4C,D). At lower BCD, the points all fall above the 1:1 line, indicating that BCD is higher than the carbon supply rate from DPP (Fig. 4D). In contrast, at higher $\mathrm{BCD}$ rates, the points are nearer to the 1:1 line, reflecting the closer balance between organic carbon supply and demand in the more eutrophic stations. In contrast to the large discrepancies in carbon supply when only DPP is considered, the linkage between BCD and TPP was much tighter, with the majority of the points falling close to the 1:1 line.
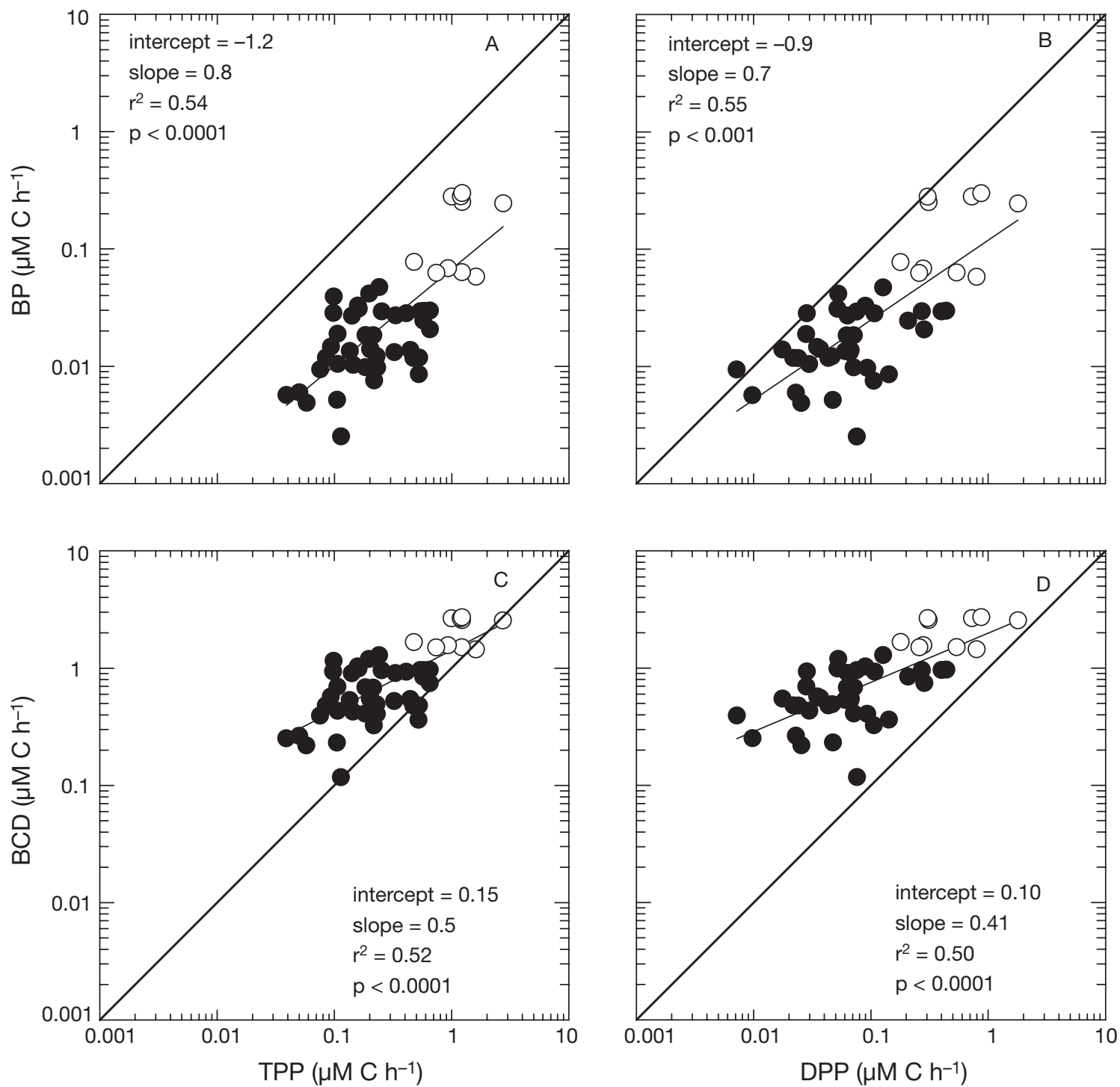

Fig. 4. Bacterial production (BP) as a function of (A) total primary production (TPP) and (B) dissolved primary production (DPP); bacterial carbon production (BCD) as a function of (C) TPP and (D) DPP. BCD was calculated from the measured BP values for each incubation using a bacterial growth efficiency calculated from the equation of del Giorgio \& Cole (1998). Data from all the light levels are plotted. O: coastal bay stations (Stns D65 and N12): oligotrophic stations 


\section{DISCUSSION}

We measured DPP, PPP and BP at 10 stations in the southwest lagoon of New Caledonia during a $10 \mathrm{~d}$ cruise in October 2004. BP was measured in the dark at the beginning and end of each primary production incubation in order to estimate the degree of linkage between primary production and BP. In all the light incubations, we observed an increase in total production (PPP and DPP); however, the relative contributions of PPP and DPP varied, with generally higher relative DPP at higher irradiances (Fig. 2, Table 2). In contrast, $\mathrm{BP}_{\text {fin }}$ generally decreased with increasing irradiance and hence DPP (Fig. 3). These results imply that there was a short-term decoupling, on the scale of hours, between the production of DPP and $\mathrm{BP}_{\text {fin }}$.

Short-term time lags in the response of $\mathrm{BP}$ to increases in primary production have been observed elsewhere, and the accumulation of DOM during the bloom periods in other environments also suggests some decoupling of DOC production and consumption, albeit on a longer timescale (Carlson et al. 1994, Fisher et al. 1998, Karl et al. 1998). Thingstad et al. (1997) proposed that it was due to a short-term 'malfunctioning microbial loop' whereby BP is limited by autotrophic competition for mineral nutrients or that specific enzymatic capabilities were absent. In our data set, the negative relationship between the $\triangle \mathrm{BP}: \mathrm{DPP}$ ratio and light points towards a reduction in DOM bioavailability at higher light levels. In other words, given that the rates of DPP were generally highest at the higher light levels, it appears that bacterial utilisation of the freshly produced DOM was reduced. Obviously, over the $4 \mathrm{~h}$ of the incubation, it is probable that there was some recycling of DPP and that any values measured are net production rates. Nevertheless, it appears that the bulk of the DPP produced was not bioavailable to the heterotrophic bacteria present.

Besides organic carbon limitation in terms of quality rather than quantity, the lack of rapid response of BP to DPP could be due to limitation in another parameter not taken into account in the incubations. Nutrient limitation, light inhibition or the fact that the bacteria present did not possess the enzymes necessary to degrade newly produced DOC have all been proposed as explanations for the lack of tight coupling between BP and DPP. Firstly, lack of enzymatic capacity is unlikely as the incubations took place over a short enough period $(4 \mathrm{~h})$ to avoid any large changes in bacterial community composition (Gattuso et al. 2002). Secondly, although light is known to affect the measurement of BP (Aas et al. 1996, Morán et al. 2001, Church et al. 2004), we did not conduct our BP incubations under natural sunlight and so it is improbable that the light intensity itself affected the uptake of the radioac- tive substrate. Indeed, our methodology measured the response of BP to light-influenced changes in photosynthesis. Finally, we used polycarbonate cell culture flasks for the incubations and it is unlikely that UV inhibition was a major problem as polycarbonate is generally considered to be UV-opaque. Thus, it is probable that some other factor, related either directly or indirectly to photon flux density, was influencing $\mathrm{BP}_{\text {fin }}$ (Fig. 3A).

Morán et al. (2001) suggested that the enhancement of BP in the dark was due to the loss of organics by phytoplankton during the switch from light to dark at the beginning of incubation. Unlike Morán et al. (2001) we did not observe a correlation between the dark: light ratio and DIN concentration, although it should be noted that our DIN concentrations were up to 10 times lower than theirs and our $\mathrm{BP}_{\text {fin }}$ values were measured in the dark. Similarly, we failed to observe a correlation between $\mathrm{PO}_{4}$ or initial DOC concentration and the dark:light bottle ratio. While the switch from light to dark could be the source of the stimulated bacterial production, it is clear that this was not on the same timescale as the incubations of Morán et al. (2001), suggesting that the effect is not transient.

When the entire data set from the different light levels was pooled, there was a positive relationship between BCD and DPP (Fig. 4D). Morán et al. (2002a) propose that only when there is a 1:1 relationship between DPP and BCD can we consider the trophic linkage between bacterioplankton and autotrophic phytoplankton to be strong. We observed wide differences in the degree of linkage between these 2 compartments that occurred over a much smaller spatial scale than that of Morán et al. (2002a). In the lagoonal oligotrophic stations, DPP is not high enough to satisfy BCD, and external sources of DOM are required to support bacterial requirements, indicating that $\mathrm{BCD}$ was not strongly linked with primary production. In contrast, in coastal waters, where DPP rates are higher, BCD can be met by primary production, assuming that all the DPP is bioavailable to bacterial heterotrophs.

We observed the inverse of Morán et al. (2002a) in their comparison of a range of coastal and offshore temperate and polar systems. In our oligotrophic lagoonal sites, DPP was clearly not enough to support $\mathrm{BCD}$. In contrast, in our nearshore sites, BCD and DPP were more strongly coupled. One obvious reason as to why we observed a different pattern may be related to the environments studied. Our measurements were made in a semi-enclosed system and it is known that residence time plays an important role in biogeochemical processes in this lagoon (Mari et al. 2007, Torréton et al. 2007). Mari et al. (2007) recently proposed that the higher rates of primary production combined with the increased residence time in the coastal bays and 
reduced TEP production rates lead to increased DOM in the water column, through reduced sedimentation. The results of the present study also support this idea. Mari et al. (2007) have shown that the percentage of DPP going into TEP production can represent up to $60 \%$ in the more oligotrophic sites, compared to $1 \%$ in the coastal bays.

An alternative explanation may reside in the bioavailability of DPP. The bioavailability to heterotrophic bacteria of both allochthonous and autochthonous DOM can be influenced by the presence of metals. Small increases in the concentration of zinc can significantly reduce the bioavailability of DPP to heterotrophic bacteria, even in the presence of excess nutrients (E. J. Rochelle-Newall et al. unpubl.). This is particularly important in the coastal bays where metal concentrations can be elevated (Migon et al. 2007). Secondly, although recently produced organic matter is often considered to be of relatively high lability (Norrman et al. 1995), work on the colonial cyanobacteria Trichodesmium has shown that DPP can be refractory to heterotrophic bacteria (Renaud et al. 2005) and this cyanobacterium is known to proliferate in this region. Thus even though DPP rates are sufficient to support BCD in the coastal sites, the accumulations of DOC observed seem to point towards a reduced bioavailability, potentially through a malfunctioning of the microbial loop (Thingstad et al. 1997).

While this may explain the accumulation of DOM in the coastal bays, it is unclear which other sources support BCD in the more oligotrophic sites. Although DPP is not enough to support BCD in the more oligotrophic sites, TPP could supply enough carbon (Fig. 4C). This seems to indicate that BCD is supported by TPP and not uniquely by the dissolved component. In other words, bacterial heterotrophs are using newly produced DPP and supplementing their requirements with DOC originating from the solubilisation of previously produced biomass following cell rupture from grazing or viral lysis. Both would result in the release of bioavailable cellular products (Lampert 1978, Fuhrman 1999) as would the solubilisation of TEP particles colonised by bacterial communities (Mari \& Kiørboe 1996). TEP can be a source of available carbon to bacterial heterotrophs, and TEP produced during photosynthesis would have been counted as PPP with the methods used in the present study. Finally, one potentially major source of organic carbon to the system is the coral barrier reef (Ferrier-Pagès et al. 2000). However, without direct measurement of the production and degradation of the difference sources, it is difficult to pinpoint which one is supporting the excess BCD.

Our results show that in the southwest lagoon of New Caledonia, an oligotrophic coral reef lagoon, the degree of linkage between bacteria and phytoplank- ton varies depending upon the environment observed. We determined that BCD could only be met by primary production in the coastal sites, and that at the oligotrophic lagoonal stations, an alternative source of DOC was necessary to meet $\mathrm{BCD}$. We also observed an inverse relationship between BP measured by the thymidine method and the photosynthetic response to light. Whether this negative relationship was due to direct light inhibition of bacterial synthesis during the $4 \mathrm{~h}$ incubation or due to a weak linkage between BCD and DPP over short timescales was not clear. Nevertheless, these results further highlight the complexity of interactions between primary production sources and secondary metabolic processes in tropical systems; they also underline the potential differences between these often ignored systems and temperate ecosystems when trying to determine carbon and nutrient budgets in coastal systems.

Acknowledgements. We thank the captain and crew of the Louis Hénin of the department of Lighthouses and Buoys, New Caledonia. P. Gérard is thanked for the nutrient analyses. We also thank 3 anonymous reviewers and the editor for their helpful comments on a prior version that greatly improved the quality of the manuscript. This research was financed by the ZoNéCo program of New Caledonia, French National program of the coastal environment (PNEC) and the IRD.

\section{LITERATURE CITED}

Aas P, Lyons MM, Pledger R, Mitchell DL, Jeffrey WH (1996) Inhibition of bacterial activities by solar radiation in nearshore waters and the Gulf of Mexico. Aquat Microb Ecol 11:229-238

Amon RMW, Benner R (1996) Bacterial utilization of different size classes of dissolved organic matter. Limnol Oceanogr 41:41-51

Borges AV, Delille B, Frankignoulle M (2005) Budgeting sinks and sources of $\mathrm{CO}_{2}$ in the coastal ocean: diversity of ecosystems counts. Geophys Res Lett 32(14):L14601, doi: 10.1029/2005GLO23053

Bouvy M, Arfi R, Cecchi P, Corbin D, Pagano M, Saint-Jean L, Thomas S (1998) Trophic coupling between bacterial and phytoplanktonic compartments in shallow tropical reservoirs (Ivory Coast, West Africa). Aquat Microb Ecol 15: 25-37

Briand E, Pringault O, Jacquet S, Torreton JP (2004) The use of oxygen microprobes to measure bacterial respiration for determining bacterioplankton growth efficiency. Limnol Oceanogr Methods 2:406-416

Carlson CA (2002) Production and removal processes. In: Hansell DA, Carlson CA (eds) Marine dissolved organic matter. Academic Press, San Diego, CA p 91-152

Carlson CA, Ducklow HW, Michaels AF (1994) Annual flux of dissolved organic carbon from the euphotic zone in the northwestern Sargasso Sea. Nature 371:405-408

Church MJ, Ducklow HW, Karl DA (2004) Light dependence of ${ }^{3} \mathrm{H}$-leucine incorporation in the oligotrophic North Pacific ocean. Appl Environ Microbiol 70:4079-4087

Cole J, Findlay S, Pace ML (1988) Bacterial production in fresh and saltwater ecosystems: a cross-system overview. Mar Ecol Prog Ser 43:1-10 
del Giorgio PA, Cole JJ (1998) Bacterial growth efficiency in natural aquatic systems. Annu Rev Ecol Syst 29:503-541

del Giorgio P, Davis J (2003) Patterns in dissolved organic matter lability and consumption across aquatic ecosystems. In: Findlay S, Sinsabaugh RL (eds) Aquatic ecosystems: interactivity of dissolved organic matter. Academic Press, Amsterdam, p 399-424

Douillet P, Ouillon S, Cordier E (2001) A numerical model for fine suspended sediment transport in the southwest lagoon of New Caledonia. Coral Reefs 20:361-372

Engel A, Passow U (2001) Carbon and nitrogen content of transparent exopolymer particles (TEP) in relation to their Alcian Blue adsorption. Mar Ecol Prog Ser 219:1-10

Ferrier-Pagès C, Leclercq N, Jaubert J, Pelegrí S (2000) Enhancement of pico- and nanoplankton growth by coral exudates. Aquat Microb Ecol 21:203-209

Fisher TR, Hagy JD, Rochelle-Newall E (1998) Dissolved and particulate organic carbon in Chesapeake Bay. Estuaries 21:215-229

Fuhrman JA (1999) Marine viruses and their biogeochemical and ecological effects. Nature 399:541-548

Fukuda R, Ogawa H, Nagata T, Koike I (1998) Direct determination of carbon and nitrogen contents of natural bacterial assemblages in marine environments. Appl Environ Microbiol 64:3352-3358

Gattuso JP, Peduzzi S, Pizay MD, Tonolla M (2002) Changes in freshwater bacterial community composition during measurements of microbial and community respiration. J Plankton Res 24:1197-1206

Holmes MR, Aminot A, Kérouel R, Hooker BA, Peterson BJ (1999) A simple and precise method for measuring ammonium in marine and freshwater ecosystems. Can J Fish Aquat Sci 56:1801-1808

Holm-Hansen O, Lorenzen CJ, Holmes RW, Strickland JDH (1965) Fluorimetric determination of chlorophyll. Rapp P-V Reun Cons Int Explor Mer 30:3-15

Jacquet S, Delesalle B, Torreton JP, Blanchot J (2006) Responses of the phytoplankton communities to increased anthropogenic influences (Southwestern Lagoon, New Caledonia). Mar Ecol Prog Ser 320:65-78

Karl DM, Hebel DV, Bjökman K, Letelier RM (1998) The role of dissolved organic matter release in the productivity of the oligotrophic North Pacific Ocean. Limnol Oceanogr 43:1270-1286

Kirchman DL, Lancelot C, Fasham M, Legendre L, Radach G, Scott M (1993) Dissolved organic matter in biogeochemical models of the ocean. In: Evans GT, Fasham MJR (eds) Towards a model of ocean biogeochemical processes, Vol 10. Springer-Verlag, Berlin, p 209-225

Lampert W (1978) Release of dissolved organic carbon by grazing zooplankton. Limnol Oceanogr 23:831-834

Marañón E, Cermeño P, Fernández E, Rodríguez J, Zabala L (2004) Significance and mechanisms of photosynthetic production of dissolved organic carbon in a coastal eutrophic ecosystem. Limnol Oceanogr 49:1652-1666

Marañón E, Cermeno P, Perez V (2005) Continuity in the photosynthetic production of dissolved organic carbon from eutrophic to oligotrophic waters. Mar Ecol Prog Ser 299:7-17

Mari X, Kiørboe T (1996) Abundance, size distribution and

Editorial responsibility: Josep Gasol,

Barcelona, Spain bacterial colonization of transparent exopolymeric particles (TEP) during spring in the Kattegat. J Plankton Res 18:969-986

Mari X, Rochelle-Newall E, Torréton JP, Pringault O, Jouon A, Migon C (2007) Water residence time: a regulatory factor of the DOM to POM transfer efficiency. Limnol Oceanogr 52:808-819

Migon C, Ouillon S, Mari X, Nicolas E (2007) Geochemical and hydrological constraints on the distribution of trace metal concentrations in the lagoon of Nouméa, New Caledonia. Estuar Coast Shelf Sci 74:756-765

Morán XAG, Massana R, Gasol JM (2001) Light conditions affect the measurement of oceanic bacterial production via leucine uptake. Appl Environ Microbiol 67:3795-3801

Morán XAG, Estrada M, Gasol JM, Pedrós-Alió C (2002a) Dissolved primary production and the strength of phytoplankton bacterioplankton coupling in contrasting marine regions. Microb Ecol 44:217-223

Morán XAG, Gasol JM, Pedrós-Alió C, Estrada M (2002b) Partitioning of phytoplanktonic organic carbon production and bacterial production along a coastal-offshore gradient in the NE Atlantic during different hydrographic regimes. Aquat Microb Ecol 29:239-252

Norrman B, Zweifel UL, Hopkinson CS, Fry B (1995) Production and utilization of dissolved organic carbon during an experimental diatom bloom. Limnol Oceanogr 40:898-907

Passow U, Alldredge AL (1995) A dye-binding assay for the spectrophotometric measurement of transparent exopolymeric particles (TEP). Limnol Oceanogr 40:1326-1335

Raimbault P, Slawyk G, Coste B, Fry J (1990) Feasibility of using an automated colorimetric procedure for the determination of seawater nitrate in the 0 to $100 \mathrm{nM}$ range: examples from field and culture. Mar Biol 104:347-351

Renaud F, Pringault O, Rochelle Newall E (2005) Effects of the colonial cyanobacterium Trichodesmium spp. on bacterial activity. Aquat Microb Ecol 41:261-270

Rochelle-Newall EJ, Pizay MD, Middelburg JJ, Boschker HTS, Gattuso JP (2004) Degradation of riverine dissolved organic matter by seawater bacteria. Aquat Microb Ecol $37: 9-22$

Stepanauskas R, Leonardson L, Tranvik LJ (1999) Bioavailability of wetland-derived DON to freshwater and marine bacterioplankton. Limnol Oceanogr 44:1477-1485

Teira E, Pazo MJ, Quevedo M, Fuentes MV, Niell FX, Fernandez E (2003) Rates of dissolved organic carbon production and bacterial activity in the eastern North Atlantic Subtropical Gyre during summer. Mar Ecol Prog Ser 249: 53-67

Thingstad TF, Hagström Å, Rassoulzadegan F (1997) Accumulation of degradable DOC in surface waters: is it caused by a malfunctioning microbial loop? Limnol Oceanogr 42:398-404

Torréton JP, Dufour P (1996) Temporal and spatial stability of bacterioplankton biomass and productivity in an atoll lagoon. Aquat Microb Ecol 11:251-261

Torréton JP, Faure V, Jouon A, Rochelle-Newall EJ, Jacquet S, Douillet P (2007) Correspondence between the distribution of hydrodynamic time parameters and the distribution of biological and chemical variables in a semi-enclosed coral reef lagoon. Estuar Coast Shelf Sci 74:766-776

Submitted: March 8, 2007; Accepted: August 24, 2007 Proofs received from author(s): February 2, 2008 